\title{
МОВНІ КЛІШЕ В СУЧАСНОМУ ІНФОРМАЦИЙНОМУ МОВЛЕННІ
}

Шарманова Н. М. Мовні кліше в сучасному інформаційному мовленні.

У статті висвітлено комунікативні й прагматичні особливості мовних кліше як регулярних стандартизованих стереотипних одиниць у мові сучасної вітчизняної тележурналістики.

Ключові слова: мовне кліше, комунікативні особливості, прагматичні особливості, мас-медійний дискурс.

() Н. М. Шарманова, 2012.

$-264-$ 
Шарманова Н. Н. Языковые клише в современной информационной речи.

В статье освещены коммуникативные и прагматические особенности языковых клише как регулярных стандартизированных стереотипных единиц в языке современной отечественной тележурналистики.

Ключевые слова: языковое клише, коммуникативные особенности, прагматические особенности, масс-медийный дискурс.

Sharmanova N. M. The language cliché in the modern informative broadcasting.

The article deals with the communicative and pragmatic peculiarities of cliché as regular standardized stereotype units in language of the modern Ukrainian television media are being considered in particular.

Key words: language cliché, communicative peculiarities, pragmatic peculiarities, discourse of media.

Мас-медійний дискурс - це та сфера професійної комунікативної діяльності, де відбивається оперативне реагування на злободенні суспільно-політичні, соціальні події та чітко простежується вплив мови ЗМІ на формування суспільних цінностей. Мова мас-медіа як віддзеркалення сучасного стану української літературної мови сприяє виробленню мовного стандарту (С. Я. Єрмоленко). Однією 3 визначальних рис мови мас-медіа $\epsilon$ «прагнення до логізації викладу, раціоналізму, певного стандарту, місткості» [20, с. 35].

Скорочення діапазону впливу друкованої публіцистики, оперативність реагування на суспільно-політичні й соціальні події, розбудова усної форми мови в теле- й радіожурналістиці, перевага лаконізму оперативних повідомлень в Інтернет-виданнях, фіксований ефірний час i обсяг друкованих знаків, дозволяють активно використовувати в мас-медійному дискурсі готових мовних одиниць, які відповідають основному конструктивному принципу публіцистичної мови - упорядкованому й регулярному чергуванню стандартизованих й експресивно забарвлених мовних конструкцій (сегментів) на різних ділянках мовного ланцюжка, на різних композиційних рівнях (Д. П. Вовчок, В.Г. Костомаров, Г. Я. Солганик).

Мета статті полягає у висвітленні прагматичних виявів кліше в мові українського телевізійного простору. Мета розвідки передбачає розв'язання низки завдань: 1) розкриття полістатусності кліше як одного 3 малодосліджених явищ природної мови; 2) 3'ясування комунікативних особливостей мовних кліше в сучасному 
інформаційному телемовленні; 3) репрезентація прагматичних ознак кліше в текстах, зафіксованих на телевізійних каналах України.

У питаннях комплексного опису механізмів номінації й комунікації особливе місце відведено стереотипним комбінаціям словесних знаків, які $\epsilon$ автономними блоками із традиційно усталеними значенням і формою. До таких одиниць належать мовні кліше, що завжди містяться в ментальному лексиконі комуніканта.

Вивчення мовних кліше не належить сьогодні до кола найбільш розроблених проблем вітчизняного мовознавства. Різні підходи до тлумачення мовної природи кліше пояснюються традиційним розумінням і новим осмисленням сутності цієї одиниці мови, широким і вузьким розумінням її обсягу (Ю. В. Рождественський).

Традиційно всі відтворювані мовні одиниці українські й зарубіжні мовознавці зараховують до фразеологізмів за широкого розуміння об’єкта фразеології (О. В. Кунін, О. Д. Райхштейн, Л. Г. Скрипник, Г. М. Удовиченко, В. Д. Ужченко та ін.). Розмежування фразем та інших стійких сполучень слів (складних термінів та найменувань, клішованих висловів, шаблонних виразів) залишається одним із головних завдань задля встановлення обсягу, меж і статусу самої фразеології [3, с. 10]. Відмежування мовних кліше від фразеологізмів у вузькому сенсі як образних аналітичних номінативних знаків мови, 3 одного боку, а з іншого, - від вільних словосполучень (номінативних знаків реалізації мови) дає можливість проаналізувати різні підходи щодо лінгвального статусу кліше, наявні в науковій літературі. На рівні надслівної номінації мовні кліше $є$ аналітичними знаками, які виконують або первинну, або повторну номінативну функцію, що i відрізняе їх від фразеологізмів як вторинних номенів [12, с. 30].

Почасти одиниці клішованого характеру є предметом вивчення лексикології чи фразеології, іноді - морфології або синтаксису, а найчастіше - стилістики. Відомі спроби виокремлення їх дослідження в окрему лінгвістичну дисципліну - фразеоматику (лінгвістичні школи О. В. Куніна, В. Хлєбди).

Клішовані мовні знаки предикативного характеру називають також прецедентними текстами (Ю. М. Караулов), усталеними комунікативними фрагментами (Б. М. Гаспаров), клішованими висловами (Є. М. Верещагін, В.Г. Костомаров), комунікативними фразеологічними висловами (М. М. Шанський). Для деяких із цих () Н. М. Шарманова, 2012. 
одиниць Н. І. Формановська використовує дефініцію «стійкі формули спілкування». А. Г. Ахмеджанова наводить цілу низку термінологічних визначень для таких мовних явищ: шаблонні фрази, стереотипні висловлювання, речення-формули, усталені фрази спілкування, фразеологізовані або стаціонарні речення [12, с. 9].

Загалом у вітчизняному мовознавстві для 3'ясування мовної специфіки кліше існують різні тлумачення: від негативного маркування - як шаблонної фрази, «заяложеного виразу» [7, с. 546], до протилежного: як мовного стереотипу з позитивною функцією, конструктивної одиниці мови [18, с. 237]. Нове розуміння дефініції «мовне кліше» знаходимо у вітчизняних термінологічних працях, укладених Ф. С. Бацевичем та О. О. Селівановою [17, с. 209; 4, с. 73].

Визнаючи багатогранність визначеного об'єкта дослідження, ми не можемо оминути і те, що дефініцію «мовне кліше» звужено до розуміння тільки стереотипних ділових висловів на зразок враховуючи сказане вище; на відміну від тощо. Клішованими вважають одиниці, які функціонують на базі словосполучення і лише в текстах офіційноділового спрямування. Усталеним $є$ погляд на кліше як стандартизовану мовну одиницю, пов'язану передусім 3 процесами стандартизації мови офіційно-ділового стилю. Питання щодо побутування мовних кліше в офіційно-діловому стилі є предметом наукового зацікавлення Н. Д. Бабич, С. П. Бибик, С. Я. Срмоленко, А. П. Коваль, Л. І. Мацько, О. Д. Пономарева та ін.

При осмисленні поняття кліше спостерігаємо апелювання до інших дефініцій: «стандартизоване словосполучення» (Р. Ф. Возна), «канцелярський зворот» (М. А. Жовтобрюх), «мовна формула-штамп» (М. М. Пещак), «канцелярський вислів-кліше» (Н. М. Сологуб), «канцелярський шаблон» (А. Ф. Марахова), «мовна формула» (Л. І. Мацько, О. М. Мацько), «стійке сполучення слів» (Д. Горбачук, Л. Коваленко) тощо [5, с. 267-278].

Поза увагою дослідників залишаються готові до вербального продукування, відтворення i сприймання мовні одиниці, які побутують не лише у спеціалізованих текстах (наукових, законодавчих, дидактичних, комп'ютерних тощо), а й у всій поліфонічній площині текстів інших типів - синкретичних i синтетичних текстах, текстах трансцендентного спілкування та щоденної комунікації. Особливе значення мають готові структурно- 
змістові блоки у синтетичних текстах (мас-медіа, Інтернет, реклами), які поєднують ознаки зазначених вище різновидів текстів.

Викладені вище підходи стосовно сутності кліше, наявні в українському й зарубіжному мовознавстві, не дають однозначної відповіді на низку питань. Залишається нерозв'язаною проблема лінгвістичної природи кліше: це знаки, сукупність різнорівневих одиниць, стилістичні засоби чи фігури мови? Крім того, обсяг самого поняття, співвідношення 3 термінами-дуплетами «шаблон», «мовний стереотип», «мовна формула» досі не набули в науковій літературі остаточного тлумачення. Відтак, актуальною на сьогодні $є$ думка про те, що в сучасній лінгвістиці «поняття "мовне кліше" не зовсім визначене. Під ним розуміють і фразеологізми, і просто частотні поєднання, а також більш складні семантичні єдності: стандартні репліки, гасла, популярні цитати та багато інше» [11, с. 57].

Аналогічно немає єдиного погляду i в потрактуванні функціональних можливостей частотних явищ мови. У лінгвістичній літературі здійснені спроби розмежувати мовне кліше i штамп. Обрану для дослідження одиницю - мовне кліше - ми розглядаємо як лінгвістичний феномен, а в мовній практиці він набуває психологічного характеру (Т. М. Дрідзе, В. В. Красних, Ю. С. Прохоров та ін.).

Визнаючи однією 3 основних функцію мовної економії, лінгвісти попереджають про те, що кліше за механічного перенесення в неприродні для них стилі перетворюються на штампи (А. П. Горбунов, Д. Е. Розенталь, О. О. Селіванова, Г. Я. Солганик та ін.). Надмірне вживання образного кліше в мові ЗМІ перетворює його на штамп: «У журналістиці штампи образного походження, можливо саме внаслідок оперативності цього виду праці, особливо живучі» $[10$, c. 245]. У низці наукових розвідок звернена увага вітчизняних дослідників саме на ці питання (Н. О. Бойченко, В. М. Кибальчич, О. Покровська, О. А. Сербенська, О. С. Снітко, Н. І. Швидка та ін.).

Спроби пояснити поширеність кліше автоматичністю використання засобів мови у процесі комунікації, певною інертністю в оперуванні лінгвістичним матеріалом, економією мовних і творчих зусиль, шаблонністю людського мислення шляхом відмови від підбору оригінальних засобів мовного вираження спрямовують на обмеження негативною оцінкою у кваліфікації цього явища. 
У сучасній зарубіжній лінгвістиці відстежується тенденція щодо визнання кліше як образного засобу мови. Укладач універсального довідника 3 німецької мови «Gutes deutsch in schrift und rede» Л. Маккензен серед готових блоків слів і зворотів мови розглядає три різновиди клішованих одиниць: 1) кліше як окрасу мови (Formeln als Redeschmuck); 2) кліше, яких потрібно уникати у процесі комунікації (Formeln, die man vermeiden soll); 3) закостенілі кліше (Erstarrte Formeln) [13, с. 152-164]. Неодноразово висловлено думку про те, що до поняття нейтрального кліше тяжіють пареміологічні одиниці (А. А. Крикманн, Г. Л. Пермяков, О. М. Саввіна та ін.).

Необхідність узагальнення, пояснення й опису комунікативнопрагматичних i когнітивних механізмів лінгвалізації буття у клішованих одиницях пояснюється соціолінгвістичними чинниками, як-от: повною реалізацією мовою своїх функцій в усіх сферах суспільного життя протягом останніх років, інтелектуалізацією суспільства, його тотальною інформатизацією та глобалізацією. Серед значної кількості усталених зворотів, наявних у телевізійній інформації, слід виокремити групу кліше, які найчастіше використовувані в 3МI, закріплені за ним і віддзеркалюють особливості стилю. Разом із лексикою ці фразеологізми і кліше впливають на стиль [6, с. 33; 19, с. 38].

Лаконізм і місткість у номінації назв (телепередач, телеанонсів, відеосюжетів, рубрик друкованої періодики й Інтернет-видань) за допомогою готових структурно-змістових блоків виразно репрезентують мовні і стильові ознаки медійного дискурсу: Живи 3 новинами (5-й канал); Головний аргумент; Про головне; Саме зараз (1-й національний телеканал).

Мовні кліше лежать в основі композиційного структурування фактичного інформаційного матеріалу, здійснюючи репрезентацію медіаподій: Підсумки дня (1-й національний телеканал); Час новин (5-й канал) тощо. Кліше співвідносяться 3 топіками у виборі аргументів i джерел інформації [15, с. 17]. Дискурс масової комунікації має властиві тільки йому знаки актуальності: Eксnерт на зв'язку (1-й національний телеканал) - та маркери нефактуального статусу інформації, зокрема у назвах телепередач Як кажуть (ТРК-11); Поза очі тощо.

Актуалізація кліше в українському інформаційному мовленні розкриває той факт, що посилання при цьому на авторитети почасти 
відображає «ідеологічні стандарти - шаблони “моди” та “стилю”» [21, с. 177], зокрема: Ближче до народу; В кабінетах; Вести діалог (1-й національний телеканал); Правила життя (СТБ).

Використання кліше в текстах телевізійного простору грунтується загалом на тих позиціях, що мовне продукування адресанта й мовна апперцепція адресата регулюють постійну суперечність між властивими людині потребами спілкування та іiі прагненням звести до мінімуму власну розумову й фізичну діяльність (А. Мартіне).

Масовий мовний вплив на читача (слухача) через кліше осмислюється 3 погляду когнітивних механізмів. За номенами впізнаваних фактів рівня побутової свідомості здійснюється інформування про важливі суспільні події: Контрольна робота $(1+1)$; Генеральне прибирання (СТБ); Господар у домі; Проти ночі (1-й національний телеканал).

У сприйнятті змісту мас-медійної інформації, що передається за допомогою наявних у мові знаків (їхніх звукових форм), мовна свідомість реципієнта намагається асоціювати задані форми 3 давно відомим змістом: Хто куди (1+1); За власним бажанням (Інтер); $3 a$ Батьківщину; Ти вдома (СТБ).

Зважаючи на це, позитивну оцінку актуалізації кліше в сучасному телемовленні визначено відповідністю ментальним стереотипам як відображенню в свідомості людей часто повторюваних явищ дійсності; автоматизацією процесу відтворення готових зручних уніфікованих формул; прагненням редукувати саму форму вираження, скорочуючи іiі склад до відомого стандарту; економією мисленнєвих зусиль, часу для обох сторін комунікації; використанням наявних словесних комплексів для вираження нових смислів і нових результатів суспільного досвіду.

Д. Розенталь і М. Теленкова наголошують на тому, що мовне кліше «створює конструктивну одиницю, яка зберігає свою семантику, а в багатьох випадках i виразність» [16, с. 168]. Визначаючи 3-посеред диференційних ознак кліше появу їх у конкретних умовах мовленнєвого акту (стереотипних ситуаціяхконтекстах) і реалізацію семантики виключно в реальному контексті, В. Гвоздєв стверджує думку про вигуковий характер мовних кліше на кшталт Так просто; Як це? (1-й національний телеканал), які можуть 
виражати реакції співбесідників і виражають емотивне значення [8, c. 168].

Формування позитивних оцінок подано в незамкнених кліше на позначення категорії заперечення: без ГМО; без консервантів; без обмежень (Новий канал); без жінок (1+1); Без шасі; Без ожеледи (СТБ); Без коментарів (5-й канал) тощо.

У писемному й усному телемовленні актуалізується метакомунікативна функція етикетних кліше. Вона репрезентує етикетність спілкування, під якою розуміють дотримання законів куртуазного спілкування, що визначають відповідно до мовної ситуації форми етикетності. До поняття «етикетне кліше», крім того, входять такі номени: мовні, рутинні, етикетні кліше чи формули, прагматичні формативи чи ідіоми, семіінтеракціональні одиниці, комунікативні фразеологізми, звороти ввічливості тощо [2, с. 6], під якими розуміють стереотипні фрази, що передають суспільні взаємини, наприклад: Доброго ранку, Україно (1-й національний телеканал); Все буде добре (СТБ); На здоров'я (1+1) і т. п.

У лінгвістичній літературі усталеними $€$ два погляди на прагматичну значущість етикетних кліше, бо, по-перше, вони мають стандартний, типізований характер. По-друге, установлення референційного відношення за допомогою мовних стереотипів $\epsilon$ несуттєвим і позбавленим інформативності: «Важливий лише факт “говоріння", установлення контакту, а не семіотична цінність... Їх уживання грунтується на традиції i служить для збереження соціальних норм, яких мовці дотримуються 3 причин емоційного характеру. Коли не вітаються в потрібних на те ситуаціях, відчувають не брак інформації, а появу негативних емоцій з приводу порушення правил поведінки» [2, с. 13]. Розглядаючи етикетні стосунки як універсалії з відповідними соціальними й психологічними ролями, особистісними взаєминами в офіційній i неофіційній сферах спілкування, В. А. Маслова зауважує з цього приводу: «Здавалося б, етикетна поведінка $\epsilon$ стандартною i стереотипною, являє собою замкнену систему, проте порушення цієї поведінки може призвести до непередбачуваних наслідків для людини й людства» [14, с. 47].

Залежно від комунікативних намірів мовців у різних інформаційних жанрах - інформаційна служба теленовин, репортаж, прес-конференція, дискусія, ток-шоу i т. п. - на телебаченні реалізується низка основних і факультативних функцій етикетних 
кліше (комунікативна, емоційна, когнітивна, репрезентативна, фатична, сугестивна, гедоністична, моделююча, психокорекційна, перформативна).

Комунікативний вияв кліше в медіатекстах має, як вище зазначено, і виразно негативну рису. Стереотипна комбінація лексем, яка використовується досить часто у процесі комунікації, може призвести до іiі кваліфікування в теорії та практиці журналістської майстерності як банального поєднання слів (В.Й. Здоровега, А. О. Капелюшний, М. Стівенс та ін.). перехід до розряду штампів дає підстави для виокремлення критеріїв негативної оцінки використання кліше в текстах мас-медіа. Серед них можемо назвати такі: утрата мінімального інформаційного «руху» смислів (Ф.С. Бацевич); несуттєве й позбавлене інформативності установлення референційного відношення за допомогою мовних стереотипів; ситуативна неспіввіднесеність, недоцільність актуалізації в текстах; висока частотність уживання зумовлює перехід до розряду штампів: Далі буде; На зв'язку; Нові серіӥ; Пряма транслячія; Прямий ефір; Спонсор показу тощо.

Мовні, стильові й композиційні штампи, визначені стандартними механізмами побудови медійного матеріалу, почасти виникають унаслідок журналістського калькування (іноді 3 порушенням професійної етики). Проте іноді цьому дається певне пояснення: «Через обмеженість часу і простору комунікатор повинен зводити велику частину інформації до іiі найпростіших елементів. Аудиторія також не має достатньо часу та енергії, аби занурюватися в усі подробиці» [21, с. 176].

Загалом же пресупозиція використання кліше розглядається як стереотипне уявлення про смисловий зв'язок між експліцитно вираженим значенням стандартної формули та імпліцитно наявним у мовній свідомості лінгвокультурним досвідом комунікантів, «їхнім загальним фондом екстралінгвістичних і лінгвістичних знань про денотативну й прагматичну ситуацію» [1, с. 224].

Експліцитне маркування в жанрах телевізійної комунікації за допомогою постійно відтворюваних мовних знаків - кліше - визначає комунікативні стратегії і мовну поведінку учасників комунікації, у тому числі й вияв можливості маніпулятивних впливів на індивідуальну й колективну свідомість, що загалом можна розглядати 
в контексті специфіки мовної культури й професійної етики тележурналіста.

Отже, соціолінгвістичні умови відображають широкі можливості використання в мас-медійному дискурсі готових мовних одиниць. Кліше як повторюваний у схожих ситуаціях мовний знак дозволяє втілювати стереотипні комунікативні смисли в текстах сучасних вітчизняних мас-медіа. Комунікативні й прагматичні функції кліше реалізуються у процесі щоденної телекомунікації.

\section{Література}

1. Алефиренко Н. Ф. Когнитивно-прагматическая фразеология как лингвистическая проблема / Н. Ф. Алефиренко // SLAVENSKA FRAZEOLOGIA I PRAGMATIKA / СЛАВЯНСКАЯ ФРАЗЕОЛОГИЯ И ПРАГМАТИКА / Uredn. Zelika Fink, Anita Hrnjak. - Zagreb : KNJIGRA, 2007. - S. 219-225.

2. Баландіна Н. Ф. Функції i значення чеських прагматичних кліше в комунікативному контексті / Надія Францівна Баландіна / НАН України, Ін-т мовознавства ім. О. О. Потебні. - К. : АСМІ, 2002. - 332 с.

3. Баран Я. А. Фразеологія у системі мови : дис. ... канд. філол. наук : 10.02 .15 загальне мовознавство / Я. А. Баран / Прикарпатський ун-т ім. Василя Стефаника. Івано-Франківськ, 1998. - 32 с.

4. Бацевич Ф. С. Словник термінів міжкультурної комунікації / Флорій Сергійович Бацевич. - К. : Довіра, 2007. - 205 с.

5. Бибик С. П. Офіційно-діловий стиль / С. П. Бибик // Українська лінгвостилістика XX - початку XXI ст. : система понять і бібліографічні джерела / За ред. С. Я. Єрмоленко. - К., 2007. - С. 267-278.

6. Вакуров В. Н. Стилистика газетных жанров / Вакуров В. Н., Кохтев Н. Н., Солганик Г. Я. - М. : Высшая школа, 1978. - С. 33.

7. Великий тлумачний словник сучасної української мови / Відп. ред. В. Т. Бусел. К. : Ірпінь, ВТФ : Перун, 2007. - 1736 с.

8. Гвоздев В. В. Контекст и некоторые проблемы прагматики клише / В. В. Гвоздев // Роль контекста в реализации семантических особенностей языковых единиц. - Курск, 1987. - С. 14-22.

9. Срмоленко С. Я. Нариси з української словесності : (стилістика та культура мови) / Світлана Яківна Єрмоленко. - К. : Довіра, 1999. - 416 с.

10. Здоровега В. Й. Теорія і методика журналістської творчості : [підручн.]. / В. Й. Здоровега. - 3-є вид. - Л.: ПАІС, 2008. - С. 245.

11. Кронгауз М. А. Семантика : [учеб. для студ. лингв. фак. высш. учеб. заведений] / Максим Анисимович Кронгауз. - М., 1995. - 208 с.

12. Лещак С. Языковое клише : прагматика, семантика и структура аналитических номинативных неидиоматических знаков в современном русском языке / Светлана Лещак / [Електронний ресурс]. - Кельце, 2006. - 161 с. // Режим доступу : http : // www.ujk.edu.pl/ leszczak

13. Маккензен Л. Немецкий язык. Универсальный справочник / Лутц Маккензен; пер. с нем. Е. Захарова. - М. : Аквариум, ООО «Издательство АСТ-ЛТД», 1998. - 592 с. 
14. Маслова В. А. Лингвокультурология : [учеб. пособие для студ. высш. учеб. заведений]. / Валентина Авраамовна Маслова. - [3-е изд., испр. ]. - М. : ИЦ «Академия», 2007. - 208 с.

15. Павлюк Л. С. Риторика, ідеологія, персуазивна комунікація / Людмила Степанівна Павлюк. - Л. : ПАІС, 2007. - 168 с.

16. Розенталь Д. Э. Словарь-справочник лингвистических терминов / Д. Э. Розенталь, М. А. Теленкова. - М. : АСТ, 2001. - 624 с.

17. Селіванова О. О. Сучасна лінгвістика : [термінологічна енциклопедія] / Олена Олександрівна Селіванова. - Полтава : Довкілля-К, 2006. - 716 с.

18. Сологуб Н. М. Кліше / Н. М. Сологуб // Українська мова. Енциклопедія. - К. : Укр. енциклопедія, 2000. - $752 \mathrm{c.}$

19. Стилистика газетных жанров / Под ред. Д. Э. Розенталя. - М. : Изд-во Московского ун-та, 1981. - $256 \mathrm{c}$.

20. Стишов О. А. Українська лексика кінця XX століття: (На матеріалі мови засобів масової інформації) / Олександр Анатолійович Стишов. - [2-ге вид.]. - К. : Пугач, 2005. - 388 с.

21. Яковець А. В. Телевізійна журналістика : теорія і практика : [посіб.]. / Анатолій Володимирович Яковець. - [2-е вид., доповн. і переробл.]. - К. : Вид. дім «Києво-Могилянська академія», 2009. - 262 с.

Стаття надійшла до редакції 16.10.2012 p. 